Article

\title{
Designing a Sustainable Temporary Grassland System by Monitoring Nitrogen Use Efficiency
}

\author{
Anamaria Mălinas ${ }^{1}$, Ioan Rotar ${ }^{1, *}$, Roxana Vidican ${ }^{1, *}$, Vasile Iuga ${ }^{1}$, Florin Păcurar ${ }^{1}$, \\ Cristian Mălinas ${ }^{2}$ and Cristina Moldovan ${ }^{3}$ \\ 1 Department of Plant Culture, Faculty of Agriculture, University of Agricultural Sciences and Veterinary \\ Medicine, 400372 Cluj-Napoca, Romania; anamaria.malinas@usamvcluj.ro (A.M.); \\ iugaflorica@yahoo.com (V.I.); florin.pacurar@usamvcluj.ro (F.P.) \\ 2 Department of Environmental Protection, Faculty of Agriculture, University of Agricultural Sciences and \\ Veterinary Medicine, 400372 Cluj-Napoca, Romania; cristian.malinas@usamvcluj.ro \\ 3 Department of Phytotechnics, Faculty of Agriculture, University of Agricultural Sciences and Veterinary \\ Medicine, 400372 Cluj-Napoca, Romania; cristina.moldovan@usamvcluj.ro \\ * Correspondence: rotarioan52@yahoo.fr (I.R.); roxana.vidican@usamvcluj.ro (R.V.); Tel.: +40-743358278 (I.R.)
}

Received: 18 December 2019; Accepted: 16 January 2020; Published: 19 January 2020

\begin{abstract}
Assessing the efficiency of nitrogen application is a valuable first step in establishing an optimum $\mathrm{N}$ fertilizer management plan. The aim of this study was to elaborate a sustainable $\mathrm{N}$ management system for sown grassland installed in temperate regions, through manipulation of nitrogen use efficiency and nitrogen response efficiency (NRE) indicators. Research was performed in western Romania. The biological material consists in two forage species of major importance for the forage base worldwide, namely Trifolium pratense L. and Lolium multiflorum Lam., in pure stands and in mixture. Both forage species were sown at two different spacings between rows $(12.5$ and $25.0 \mathrm{~cm})$ and were fertilized with nitrogen (N) in three doses (N0-control, N50-fertilized with $50 \mathrm{~kg} \mathrm{~N} \mathrm{ha}^{-1}$ and N100-fertilized with $100 \mathrm{~kg} \mathrm{~N} \mathrm{ha}^{-1}$ ). The studies were made in 2016 and 2017, years very different from each other in matter of rainfalls. The results revealed a different behavior of the three sward types analyzed: while in Trifolium pratense monoculture and in the mixture of the two species studied, less $\mathrm{N}$ was removed than was applied; on the other hand Lolium multiflorum monoculture used a high proportion of the $\mathrm{N}$ applied, being at the limit to access $\mathrm{N}$ from the organic pool or residual $\mathrm{N}$ from fertilizer applications to a preceding crop.
\end{abstract}

Keywords: sustainability; forage mixture; nitrogen fertilization; nitrogen-use efficiency; nitrogen-response efficiency; crude protein

\section{Introduction}

Meeting societal demand for food is a global challenge as recent estimates indicate that global crop demand will increase by $100 \%$ to $110 \%$ from 2005 to 2050 [1]. Providing higher quantities of food delivered through a sustainable agricultural system is a major challenge and is an important and current concern of both agronomic scientists and farmers.

The use of synthetic fertilizers in agriculture is fundamental for sustaining the growing population worldwide [2]. Among the most important nutrients nitrogen $(\mathrm{N})$ holds an outstanding role in agricultural production. The growth in livestock production, the specialization and agglomeration of livestock production systems, and the poor management of manure nitrogen all contribute to the low efficiency of nitrogen use in the food system [3].

Sustainable nutrient management must be both efficient and effective to deliver anticipated economic, social and environmental benefits. As the cost of nutrients climb, profitable use puts 
increased emphasis on high efficiency, and the greater nutrient amounts that higher yielding crops remove means that higher nutrient inputs will likely be needed and are at risk of loss from the system [4]. Management of $\mathrm{N}$ resources is important, especially in food production, as agriculture is the biggest user of anthropogenic $\mathrm{N}$ in the world. The negative impacts of $\mathrm{N}$ due to food production are caused by a general decrease in the nitrogen use efficiency (NUE) in most regions of the world [5,6].

Nutrient use efficiency (NUE) is a critically important concept in the evaluation of crop production systems [7]. It can be greatly impacted by fertilizer management as well as by soil and plant-water management. The objective of nutrient use is to increase the overall performance of cropping systems by providing economically optimum nourishment to the crop while minimizing nutrient losses from the field. NUE addresses some but not all aspects of that performance. Therefore, system optimization goals necessarily include overall productivity as well as NUE. Improved nutrient use efficiency has a significant role to play in the development of more sustainable dairy production systems [8].

Nitrogen losses in air [9] and to groundwater by leaching are higher in intensively-managed grasslands than in arable crops [10]. Therefore, in order to improve the sustainability of grassland husbandry it is necessary to take into account the environmental risk through nitrogen losses associated with nitrogen management.

Nutrient response efficiency (NRE) is a measure of ecosystem functioning that integrates productivity and the retention of nutrients [11]. NRE is an index that reflects the ability of plants to acquire $\mathrm{N}$ from the soil and to use it for biomass production once it is taken up [12], and thus it is a better index if biomass production is the main goal (as is the case in most temperate grasslands). Using $\mathrm{N}$-fertilizer in forage grass must be well thought because over-application of $\mathrm{N}$-fertilizer can promote excess of forage biomass above the capacity of consumption of animal grazing; thus the stocking rate needs to be adjusted in accordance with forage availability [13]. In forage research, the application of NUE could be a useful tool to select proper forage mixture with higher capacity of production under optimum $\mathrm{N}$-fertilizer rate. Forage mixtures formed of red clover and Italian ryegrass are, for example, very successful and are capable of generating very high yields, even on soils less supplied in mineral elements. Italian ryegrass is a species with elevated nitrogen requirements, so in association with red clover it will use almost all the nitrogen fixed by the leguminous species $[14,15]$. The productivity and botanical composition, especially of temporary grassland, are influenced markedly by nitrogen and water availability [16]. The improvement of NUE and NRE can deliver higher quantity and quality of dry matter production on grassland. In this frame, the aim of our study is to design a sustainable temporary grassland system by monitoring the nitrogen response efficiency (NRE) and nitrogen use efficiency (NUE). The species studied were red clover and Italian ryegrass. These two species are of great importance for the forage base worldwide both from qualitative and economic points of view. Lolium species are the most important grass species sown in temperate Europe [17] and in Romania, especially, due to their high protein content and great digestibility. Red clover is suitable in mixtures with grasses that enhance ensiling capacity and reduce damage to clover plants by pathogens and means of mechanization. An increased interest in growing forage legumes, including red clover was noticed in the last decade, mainly because of increasing energy costs and deteriorating environmental effects of synthetic nitrogen use [18]. In order to achieve the proposed objectives the following data were recorded: dry matter yield (DM) and crude protein yield (CP; \%) of red clover and Italian ryegrass in pure stands and in mixture, NUE (\%) and NRE ( $\mathrm{kg}$ biomass $\mathrm{kg} \mathrm{N}^{-1}$ ) for both species in monoculture and in mixture.

\section{Materials and Methods}

\subsection{Study Site}

The experiment was carried out in Chinteni commune, Cluj County, Romania, in 2016 and 2017. During the study period, mean annual temperature and annual precipitation were $10^{\circ} \mathrm{C}$ and $816 \mathrm{~mm}$ in 2016, respectively $9.95^{\circ} \mathrm{C}$ and $560 \mathrm{~mm}$ in 2017. The dominating soil type is an alluviosol calcaric, with a 
sandy-loamy texture. Chemical analysis of the soil shows a weak alkaline reaction, with medium humus content and well supplied with mineral nitrogen (Table 1).

Table 1. Soil characteristics in the experimental site ${ }^{1}$.

\begin{tabular}{cc}
\hline Agrochemical Index & Value \\
\hline $\mathrm{pH}$ in $\mathrm{H}_{2} \mathrm{O}$ & 8.10 \\
Humus $(\%)$ & 3.11 \\
$\mathrm{CaCO}_{3} \%$ & 5 \\
Nitrogen index $(\mathrm{IN} ; \%)$ & 3.65 \\
Total nitrogen (Nt; \%) & 0.18 \\
Mineral nitrogen (Nmin; ppm) & 34.96 \\
\hline
\end{tabular}

${ }^{1}$ The chemical analysis of the soil were delivered by specialists from the Department of Pedology, University of Agricultural Sciences and Veterinary Medicine from Cluj-Napoca, Romania.

\subsection{Experimental Set Up}

The experimental protocol was based on the factorial combination of 2 seeding spacings between the rows $(12.5$ and $25 \mathrm{~cm})$ and 3 doses of nitrogen $\left(0 \mathrm{~kg} \mathrm{~N} \mathrm{ha}^{-1}\right.$ year $^{-1}, 50 \mathrm{~kg} \mathrm{~N} \mathrm{ha}^{-1}$ year $^{-1}$ and $100 \mathrm{~kg}$ $\mathrm{N} \mathrm{ha}^{-1}$ year $^{-1}$ ), with 3 replications. The biological material consisted of red clover and Italian ryegrass in pure stands and mixtures resulting in 3 sward types, as it is presented in Table 2.

Table 2. The studied sward types.

\begin{tabular}{|c|c|c|}
\hline Species & Experimental Plots & Sward Type \\
\hline \multirow{2}{*}{ Trifolium pratense } & $\begin{array}{l}\text { Tp_mono1, } \\
\text { Tp_mono2, } \\
\text { Tp_mono3 }\end{array}$ & $\begin{array}{l}\text { monoculture sown on } 12,5 \mathrm{~cm} \text { : unfertilized and fertilized } \\
\text { with } 50 \mathrm{~kg} \mathrm{~N} \mathrm{ha}^{-1} \text { year }^{-1} \text { and } 100 \mathrm{~kg} \mathrm{~N} \mathrm{ha}^{-1} \text { year }^{-1}\end{array}$ \\
\hline & $\begin{array}{l}\text { Tp_mono4, } \\
\text { Tp_mono5, } \\
\text { Tp_mono6 }\end{array}$ & $\begin{array}{l}\text { monoculture sown on } 25 \mathrm{~cm} \text { : unfertilized and fertilized with } \\
50 \mathrm{~kg} \mathrm{~N} \mathrm{ha}^{-1} \text { year }^{-1} \text { and } 100 \mathrm{~kg} \mathrm{~N} \mathrm{ha}^{-1} \text { year }^{-1}\end{array}$ \\
\hline \multirow{2}{*}{ Lolium multiflorum } & $\begin{array}{l}\text { Lm_mono1, } \\
\text { Lm_mono2, } \\
\text { Lm_mono3 }\end{array}$ & $\begin{array}{l}\text { monoculture sown on } 12,5 \mathrm{~cm} \text { : unfertilized and fertilized } \\
\text { with } 50 \mathrm{~kg} \mathrm{~N} \mathrm{ha}^{-1} \text { year }^{-1} \text { and } 100 \mathrm{~kg} \mathrm{~N} \mathrm{ha}^{-1} \text { year }^{-1}\end{array}$ \\
\hline & $\begin{array}{l}\text { Lm_mono4, } \\
\text { Lm_mono5, } \\
\text { Lm_mono6 }\end{array}$ & $\begin{array}{l}\text { monoculture sown on } 25 \mathrm{~cm} \text { : unfertilized and fertilized with } \\
50 \mathrm{~kg} \mathrm{~N} \mathrm{ha}^{-1} \text { year }^{-1} \text { and } 100 \mathrm{~kg} \mathrm{~N} \mathrm{ha}^{-1} \text { year }^{-1}\end{array}$ \\
\hline \multirow{2}{*}{$\begin{array}{l}\text { Mixture of Tp } \\
\text { and Lm }\end{array}$} & $\begin{array}{l}\text { TpLm_mixt1, } \\
\text { TpLm_mixt2, } \\
\text { TpLm_mixt3 }\end{array}$ & $\begin{array}{l}\text { mixture of Tp and Lm sown on } 12,5 \mathrm{~cm} \text { : unfertilized and } \\
\text { fertilised with } 50 \mathrm{~kg} \mathrm{~N} \mathrm{ha}^{-1} \text { year }^{-1} \text { and } 100 \mathrm{~kg} \mathrm{~N} \mathrm{ha}^{-1} \text { year }^{-1}\end{array}$ \\
\hline & $\begin{array}{l}\text { TpLm_mixt4, } \\
\text { TpLm_mixt5, } \\
\text { TpLm_mixt6 }\end{array}$ & $\begin{array}{l}\text { mixture of Tp and Lm sown on } 25 \mathrm{~cm} \text { : unfertilized and } \\
\text { fertilised with } 50 \mathrm{~kg} \mathrm{~N} \mathrm{ha}^{-1} \text { year }^{-1} \text { and } 100 \mathrm{~kg} \mathrm{~N} \mathrm{ha}^{-1} \text { year }^{-1}\end{array}$ \\
\hline
\end{tabular}

At each harvest, dry matter yield (DM), crude protein content (CP) and NUE (\%) were assessed. Data presented in this paper are the sum of 3 cuts performed on April, July and beginning of September months for each experimental year.

\subsection{Dry Matter Production, Protein Content, Plant N Uptake and Nitrogen Use Efficiency and Response (NUE and NRE)}

Dry mass of the biomass was determined by oven-drying at $60^{\circ} \mathrm{C}$ until constant mass was obtained.

The protein content of feeds was determined using the Kjeldahl method, which has as a basis the digestion of the sample with sulfuric acid in the presence of catalysts [19]. Nitrogen use efficiency can be calculated using a wide range of methods. Usually, NUE (\%) has been estimated using world N consumption and crop production, but on macro scales [20]. In this research we applied the Difference Method after [21]:

$$
\operatorname{NUE}(\%)=(\mathrm{Nf}-\mathrm{Nc}) / \mathrm{R}
$$


where:

$\mathrm{Nf}$ - total nitrogen of fertilized crop

Nc-total nitrogen of control variant (unfertilized)

$\mathrm{R}$-rate of $\mathrm{N}$ fertilizer applied

In our study, NRE is calculated after Pastor and Bridgham (1999) as:

$$
\text { NRE }\left(\mathrm{kg} \text { biomass } \mathrm{kg} \mathrm{N}^{-1}\right)=\text { Nuptake/Nsupply } \times \text { DM/Nuptake }
$$

where:

Nuptake (after Hiremath and Ewel, 2001)—Plant $\mathrm{N}$ uptake $\left(\mathrm{kg} \mathrm{N} \mathrm{ha}^{-1} \mathrm{year}^{-1}\right)=$ Ntotal $(\mathrm{kg} \mathrm{N}$ $\left.\mathrm{kg}^{-1}\right) \times \mathrm{DM}\left(\mathrm{kg} \mathrm{ha}^{-1}\right.$ year $\left.^{-1}\right)$

Nsupply—rate of fertilizer;

DM ( $\mathrm{kg} \mathrm{ha}^{-1}$ year $\left.^{-1}\right)$ —dry matter yield.

$\mathrm{NRE}$ is inversely correlated with $\mathrm{N}$ lost, e.g., through nitrate $\left(\mathrm{NO}_{3}{ }^{-}\right)$leaching and gaseous $\mathrm{N}$ emissions. A large NRE indicates a large biomass production per unit of soil available N. Therefore a large NRE may contribute to the reduction of reactive $\mathrm{N}$ in the soil, which affects water and air pollution as well as the emission of greenhouse gases [22].

\subsection{Statistical Analyses}

The effects of treatment on biomass yield, protein content, plant $\mathrm{N}$ uptake, NRE and NUE were assessed using descriptive statistics by Statistica vs 10 (developed by StatSoft in the year 2010), t-test for single means and partial correlations. Effects were accepted as statistically significant if $p \leq 0.05$.

\section{Results}

\subsection{Dry Matter Production}

In 2016, biomass yield ranged from $8860.06 \mathrm{~kg} \mathrm{ha}^{-1}$ year ${ }^{-1}$ recorded on Lm_mono to $13810.55 \mathrm{~kg} \mathrm{ha}^{-1}$ year $^{-1}$ recorded on TpLm_mixt (Table 2). Fertilization increased biomass yield, and plots treated with $100 \mathrm{~kg} \mathrm{~N} \mathrm{ha}^{-1}$ year $^{-1}$ recorded the highest yield. All the sward types achieved the highest yields using $12.5 \mathrm{~cm}$ sowing distance between rows. In 2017, biomass yield ranged from $8500.00 \mathrm{~kg} \mathrm{ha}^{-1}$ year $^{-1}$ recorded on Lm_mono to $13670.66 \mathrm{~kg} \mathrm{ha}^{-1}$ year $^{-1}$ recorded on TpLm_mixt (Table 3). Analyzing the productions recorded in the 2 experimental years, results showed higher yields in 2016 for all the sward types analyzed.

Very significant interactions between sward type $\times$ seeding density were recorded, while interactions between sward type $\times \mathrm{N}$ fertilization and $\mathrm{N}$ fertilization $\times$ seeding density were insignificant from statistical point of view. 
Table 3. Effect of nitrogen fertilization, sowing spacing between rows and sward type on the dry matter yield in 2016 and 2017.

\begin{tabular}{|c|c|c|c|c|}
\hline Factor & Factor Level & $\begin{array}{l}\text { DM Yield in } 2016 \\
\left(\mathrm{~kg} \mathrm{ha}^{-1} \text { year }^{-1}\right)\end{array}$ & $\begin{array}{l}\text { DM Yield in } 2017 \\
\left(\mathrm{~kg} \mathrm{ha}^{-1} \text { year }^{-1}\right)\end{array}$ & $p$-Value \\
\hline \multirow{3}{*}{ Sward type } & Tp_mono & $11,720.87$ & $11,060.14$ & \multirow{3}{*}{$* * *$} \\
\hline & Lm_mono & 8860.06 & 8500.00 & \\
\hline & TpLm_mixt & $13,810.55$ & $13,670.66$ & \\
\hline \multirow{3}{*}{$\mathrm{N}$ fertilization } & 0 & 9240.14 & 8890.43 & \multirow{3}{*}{$* * *$} \\
\hline & 50 & $11,920.09$ & 1170.00 & \\
\hline & 100 & $13,130.19$ & 1266.13 & \\
\hline \multirow{2}{*}{ Seeding density } & 12.5 & $11,930.12$ & 1145.19 & \multirow{2}{*}{$* * *$} \\
\hline & 25 & $10,980.15$ & 1072.98 & \\
\hline \multicolumn{4}{|c|}{ Interaction Sward type $\times \mathrm{N}$ fertilization } & $* *$ \\
\hline \multicolumn{4}{|c|}{ Interaction Sward type $\times$ Seeding density } & $* * *$ \\
\hline \multicolumn{4}{|c|}{ Interaction $\mathrm{N}$ fertilization $\times$ Seeding density } & $* *$ \\
\hline
\end{tabular}

Note: ${ }^{* *}: p<0.01$-significant (S, confidence $99 \%$ ). ${ }^{* * *}: p<0.001$-highly significant (HS, confidence 99.9\%).

\subsection{Crude Protein Content and Plant N Uptake}

Crude protein (CP) ranged from $12.19 \%$ to $16.44 \%$ in 2016, the highest content being reported for Tp_mono (Table 4). In 2017 CP recorded values between $11.20 \%$ and $16.29 \%$, with the highest content being Tp_mono. Fertilization increased CP content proportional with the $\mathrm{N}$ doses for all the sward types. The lowest protein content was obtained on monoculture with $\mathrm{Lm}$. Results showed that interaction between sward type $\times$ seeding density, between sward type $\times \mathrm{N}$ fertilization and $\mathrm{N}$ fertilization $\times$ seeding density were non-significant from statistical point of view.

Table 4. Crude protein content in monoculture and mixture.

\begin{tabular}{|c|c|c|c|c|}
\hline Factor & Factor Level & $\begin{array}{c}\text { CP Yield in } 2016 \\
(\%)\end{array}$ & $\begin{array}{l}\text { CP Yield in } 2017 \\
(\%)\end{array}$ & $p$-Value \\
\hline \multirow{3}{*}{ Sward type } & Tp_mono & 16.44 & 16.29 & \multirow{3}{*}{$* * *$} \\
\hline & Lm_mono & 12.19 & 11.20 & \\
\hline & TpLm_mixt & 13.21 & 12.23 & \\
\hline \multirow{3}{*}{$\mathrm{N}$ fertilization } & 0 & 13.53 & 12.86 & \multirow{3}{*}{$* * *$} \\
\hline & 50 & 14.00 & 13.13 & \\
\hline & 100 & 14.34 & 13.73 & \\
\hline \multirow{2}{*}{ Seeding density } & 12.5 & 14.24 & 13.42 & \multirow{2}{*}{$* * *$} \\
\hline & 25 & 13.67 & 13.06 & \\
\hline \multicolumn{4}{|c|}{ Interaction Sward type $\times \mathrm{N}$ fertilization } & * \\
\hline \multicolumn{4}{|c|}{ Interaction Sward type $\times$ Seeding density } & * \\
\hline \multicolumn{4}{|c|}{ Interaction $\mathrm{N}$ fertilization $\times$ Seeding density } & * \\
\hline
\end{tabular}

Note: *: $p>0.05$-non-significant (NS); ${ }^{* * *}: p<0.001$-highly significant (HS, confidence $99.9 \%$ ).

Plant $\mathrm{N}$ uptake in 2016 ranged from $176.77 \mathrm{~kg} \mathrm{~N} \mathrm{ha}^{-1}$ year $^{-1}$ in $\mathrm{Lm}_{-}$mono and $365.90 \mathrm{~kg} \mathrm{~N}$ ha $^{-1}$ year $^{-1}$ in TpLm_mixt (Figure 1). In 2017 plant $\mathrm{N}$ uptake increased up to $433.87 \mathrm{~kg} \mathrm{~N} \mathrm{ha}^{-1}$ year $^{-1}$ in TpLm_mixt, while in TpLm_mixt and Lm_mono the results were smaller than in 2016. Fertilization with $100 \mathrm{~kg} \mathrm{~N}$ ha $^{-1}$ year $^{-1}$ gave the highest values for plant $\mathrm{N}$ uptake and 12.5 spacing between rows. 


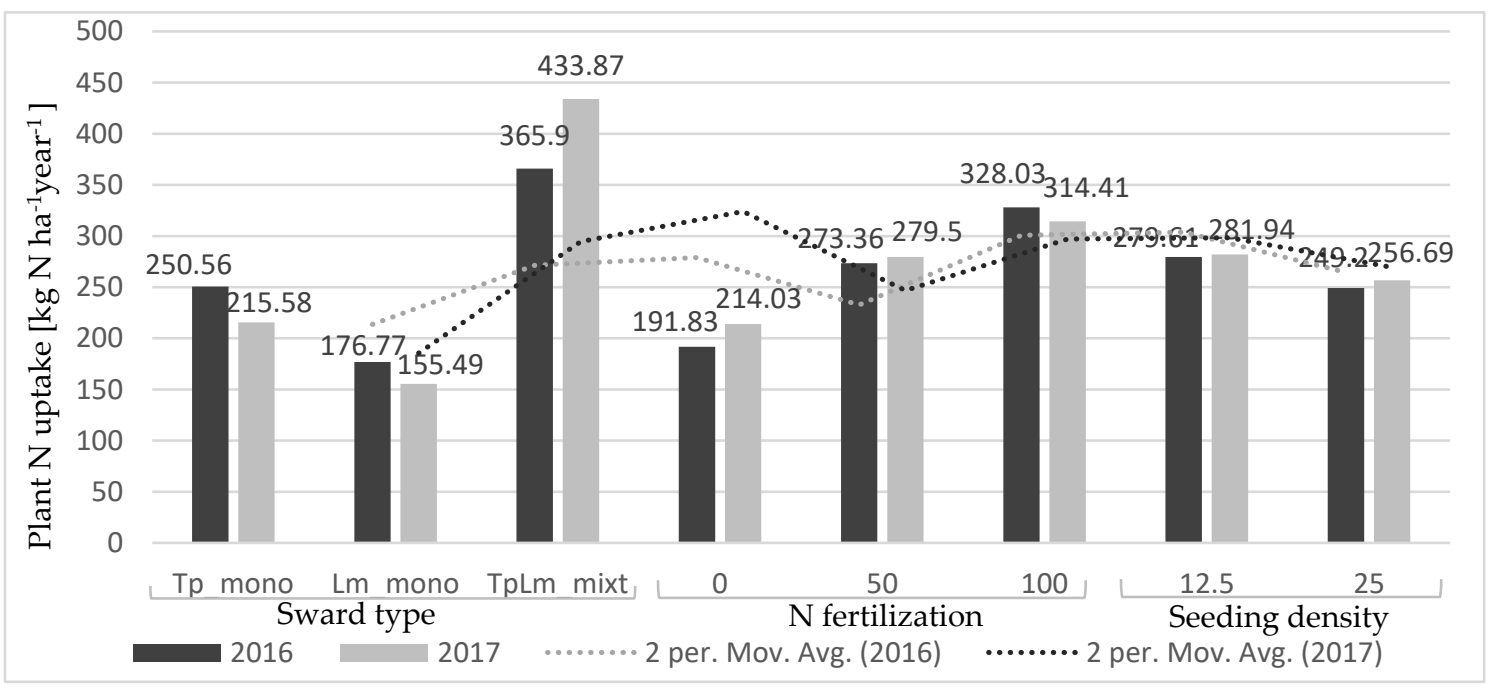

Figure 1. $\mathrm{N}$ uptake in monoculture and mixture.

\subsection{Nitrogen Response Efficiency (NRE)}

NRE in 2016 varied in from $139.24 \mathrm{~kg}$ biomass kg N supply ${ }^{-1}$ in Lm_mono to $224.66 \mathrm{~kg}$ biomass $\mathrm{kg} \mathrm{N}$ supply ${ }^{-1}$ in Tp_mono (Table 5). Fertilization influenced NRE expressing a larger efficiency in unfertilized plots compared to those fertilized. Differences were recorded also when seeding density was analyzed.

Table 5. $\mathrm{N}$ response efficiency in monoculture and mixture.

\begin{tabular}{|c|c|c|c|c|c|c|c|c|}
\hline \multirow[b]{2}{*}{ Factor } & \multirow[b]{2}{*}{ Treatments } & \multirow[b]{2}{*}{$n$} & \multicolumn{3}{|c|}{2016} & \multicolumn{3}{|c|}{2017} \\
\hline & & & $\begin{array}{c}\text { NRE } \\
\text { (kg biomass kg }^{\text {N supply }}{ }^{-1} \text { ) }\end{array}$ & SE & $p$ & $\begin{array}{c}\text { NRE } \\
\text { (kg biomass kg } \\
\text { N supply }{ }^{-1} \text { ) }\end{array}$ & SE & $\mathbf{P}$ \\
\hline \multirow{3}{*}{ Sward type } & Tp_mono & 12 & 224.66 & 18.53 & $* * *$ & 183.16 & 20.83 & $* * *$ \\
\hline & Lm_mono & 12 & 139.24 & 8.81 & $* * *$ & 136.81 & 9.79 & $* * *$ \\
\hline & TpLm_mixt & 12 & 223.63 & 20.40 & $* * *$ & 295.04 & 20.63 & $* * *$ \\
\hline \multirow{3}{*}{$\mathrm{N}$ fertilization } & 0 & 18 & 440.16 & 22.50 & $* * *$ & 461.23 & 22.71 & $* * *$ \\
\hline & 50 & 18 & 215.03 & 16.84 & $* * *$ & 250.08 & 16.82 & $* * *$ \\
\hline & 100 & 18 & 148.87 & 16.43 & $* * *$ & 159.92 & 20.22 & $* * *$ \\
\hline \multirow{2}{*}{ Seeding density } & 12.5 & 18 & 193.10 & 16.64 & $* * *$ & 198.07 & 19.43 & $* * *$ \\
\hline & 25 & 18 & 198.58 & 16.48 & $* * *$ & 211.93 & 23.40 & $* * *$ \\
\hline
\end{tabular}

\subsection{Nitrogen Use Efficiency (NUE)}

Our findings show a different reaction of species to NUE in both experimental years (Table 6). In 2016 the highest NUE was recorded in Lm_mono (86.28\%) while the smallest NUE was recorded in Tp_mono (47.81\%). The same reaction of species was observed also in 2017 despite the NUE values being non-significantly increased. 
Table 6. $\mathrm{N}$ use efficiency in monoculture and mixture.

\begin{tabular}{|c|c|c|c|c|c|c|c|c|}
\hline \multirow[b]{2}{*}{ Factor } & \multirow[b]{2}{*}{ Treatments } & \multirow[b]{2}{*}{$n$} & \multicolumn{3}{|c|}{2016} & \multicolumn{3}{|c|}{2017} \\
\hline & & & $\begin{array}{c}\text { NUE } \\
(\%)\end{array}$ & SE & $p$ & $\begin{array}{c}\text { NUE } \\
(\%)\end{array}$ & $\mathrm{SE}$ & $p$ \\
\hline \multirow{3}{*}{ Sward type } & Tp_mono & 18 & 47.81 & 1.28 & $* * *$ & 50.62 & 1.28 & $* * *$ \\
\hline & Lm_mono & 18 & 86.28 & 7.76 & $* * *$ & 87.17 & 5.35 & $* * *$ \\
\hline & TpLm_mixt & 18 & 58.45 & 13.91 & $* * *$ & 40.68 & 1.75 & $* * *$ \\
\hline \multirow{3}{*}{$\mathrm{N}$ fertilization } & 0 & 18 & 50.72 & 1.84 & $* * *$ & 55.73 & 1.98 & $* * *$ \\
\hline & 50 & 18 & 46.03 & 13.33 & $* * *$ & 47.83 & 2.03 & $* * *$ \\
\hline & 100 & 18 & 41.02 & 0.97 & $* * *$ & 44.16 & 1.45 & $* * *$ \\
\hline \multirow{2}{*}{ Seeding density } & 12.5 & 18 & 71.62 & 1.56 & $* * *$ & 59.25 & 5.24 & $* * *$ \\
\hline & 25 & 18 & 56.74 & 4.55 & $* * *$ & 59.73 & 4.21 & $* * *$ \\
\hline
\end{tabular}

\section{Discussion}

Red clover (Trifolium pretense L.) and Italian ryegrass (Lolium multiflorum Lam.) provide forage high in protein and digestibility which facilitates high intake by animals and thus can offer considerable benefits in livestock systems in Romania [23]. Further, red clover is a forage legume appreciated especially for its high rate of biological nitrogen fixation [24]. Therefore, if a sustainable grass-legume forage system is required, red clover is one of the most suitable candidate legume species. These findings are confirmed also by our research, which show that the best performing species-in terms of the best yields-is red clover, when monocultures are considered.

Eventually in red clover culture one should take into account that for good persistence and high productivity this species requires an annual rainfall of at least $700 \mathrm{~mm}$ [25]. Our results highlighted that the average annual yield was significantly affected by rainfall in 2017, such that the decreased annual rainfall recorded in the second year resulted in lower yields for both species sown in monoculture. Crude protein was similarly affected by rainfall and its concentration decreased from $16.44 \%$ in 2016 to $16.29 \%$ in 2017 in red clover; and from $12.19 \%$ in 2016 to $11.20 \%$ in 2017 in Italian ryegrass; and from $13.21 \%$ in 2016 to $12.23 \%$ in 2017 in mixture (Table 3).

In order to be the most efficient system for a given level of growth resources, a mixture has to perform not only better than the average of all the species grown in monoculture (over-yielding), but at least as well as the monoculture of the highest yielding species [26]. Our results show that the best performing sward type is TpLm_mixt, which delivered a very significant increase in yield of $13,810.55 \mathrm{~kg} \mathrm{ha}^{-1}$ in 2016 compared to Tp_mono DM production of $11,720.87 \mathrm{~kg} \mathrm{ha}^{-1}$ and Lm_mono with $8860.06 \mathrm{~kg} \mathrm{ha}^{-1}$. In $2017 \mathrm{TpLm} \_$mixt also delivered a very significant increase in yield of $13,670.66 \mathrm{~kg} \mathrm{ha}^{-1}$ compared to Tp_mono with $11,060.14 \mathrm{~kg} \mathrm{ha}^{-1}$ and Lm_mono with $8500.00 \mathrm{~kg} \mathrm{ha}^{-1}$.

Grass-legume forage mixtures' high production potential can be greatly impacted by the technology applied (fertilization, distance between rows, species). Among the technological factors with great influence on plant development and performance stands the distance between rows. Our results pointed out that a higher seeding density is more favorable for the forage species tested in this experiment since very significant increases in yield production and $\mathrm{CP}$ are recorded on experimental plots sown on $12.5 \mathrm{~cm}$. Our findings are confirmed by the scientific literature since other researchers already stated also that grass-legume mixture have better development at higher seeding density translated through higher yields [27].

Fertilization is one of the most important technological factors with great impact in agricultural production. Nitrogen is a key nutrient, vital for the survival of humans and all other living organisms [25] and therefore is frequently applied in almost any crop system. The synthesis of mineral nitrogen fertilizer is energy-intensive and its application in large quantities is associated with negative environmental 
impact [28]. If a sustainable forage system is desired to be installed solutions to reduce $\mathrm{N}$ fertilization must be found. As we showed in our experiment monocultures of highly productive key forage species like red clover can deliver high forage yields even when small or medium amounts of $\mathrm{N}$ fertilizer are applied. Therefore the inclusion of red clover in forage mixture could entailed not only yields benefits but also environmental ones.

As agronomic researchers we should always keep in mind the importance of $\mathrm{N}$ management, as agriculture is the biggest user of anthropogenic $\mathrm{N}$ in the world. The negative impacts of $\mathrm{N}$ due to our food production are caused by a general decrease in the nitrogen use efficiency (NUE) in most regions of the world [29]. Considering the $\mathrm{N}$ supply analyzed in our study, a linear increase of plant $\mathrm{N}$ uptake was reflected with increasing $\mathrm{N}$ fertilization. Forage plants uptake the majority of $\mathrm{N}$ through nitrate $\left(\mathrm{NO}_{3}{ }^{-} \mathrm{N}\right)$ and ammonium $(\mathrm{NH}-\mathrm{N})$ [30], which depend on their presence in soil solution. Improvement of $\mathrm{N}$-availability to forage grass could be enhanced by using a mixture of legumes and grass species.

We covered in our study 3 sward composition in order to find out the most suitable forage species in designing a sustainable temporary grassland system. Our findings show that sward composition influenced also the plant $\mathrm{N}$ uptake such that the highest values were recorded on TpLm_mixt while the smallest values were registered in Lm_mono. Other researchers also pointed out that the use of a mixture formed by forage legume and gramineas could be quite efficient in reducing $\mathrm{N}$-fertilizer rate due to the legumes' capacity to fix molecular $\mathrm{N}$ from atmosphere, but it is still a challenge to maintain the right proportion of these two species without competition, because the legume tends to disappear due to competition [31,32]. When seeding density is analyzed our findings show that higher plant $\mathrm{N}$ uptake are recorded on higher sowing spacing.

In terms of NUE, our findings show that NUE is significantly higher in unfertilized compared to fertilized plots. In order to increase $\mathrm{N}$-fertilizer efficiency in forage grasses, one must keep in mind that the concepts of best management practices (BMPs) for fertilizer application must be followed, which combines the 'Right source, Right rate, Right place, and Right time' (4R) nutrient stewardship model [33,34].

In addition we found that plant species diversity had a great influence on NUE, the highest value being recorded in $\mathrm{Lm} \_$mono. This value indicates that $\mathrm{N}$ applied was used differently according to the type of sward. It appears that in the Tp_mono and TpLm_mixture, less $\mathrm{N}$ is being removed than has been applied, while some of the applied $\mathrm{N}$ is left in the soil and may be used by the next crop. On the other hand Lm_mono used a high proportion of the $\mathrm{N}$ applied being at the limit to access $\mathrm{N}$ from the organic pool or residual $\mathrm{N}$ from fertilizer applications to a preceding crop.

Nitrogen response efficiency (NRE) is an index of plant productivity per unit of available $\mathrm{N}$ and even its great importance in evaluating forage cultures' nitrogen balance is crucial. However, information about NRE in sown or semi-natural grassland is extremely limited [35-37]. Our findings show that NRE was largely influenced by fertilization; its value decreased as fertilization increased. Results were similar with those reported by [37], which pointed out that NRE (which they termed ecosystem-level NUE) was negatively correlated with mean annual net nitrification rate, used as an index of soil $\mathrm{N}$ supply. The smaller NRE of the fertilized than unfertilized plots was caused by decreases in both $\mathrm{N}$ uptake efficiency and NUE. It was significantly positively related to $\mathrm{N}$ uptake efficiency $(p<0.0001$; Figure 2). The largest NRE was found in Tp_mono swards, intermediate NRE in TpLm_mixt swards and smallest NRE in Lm_mono swards. 


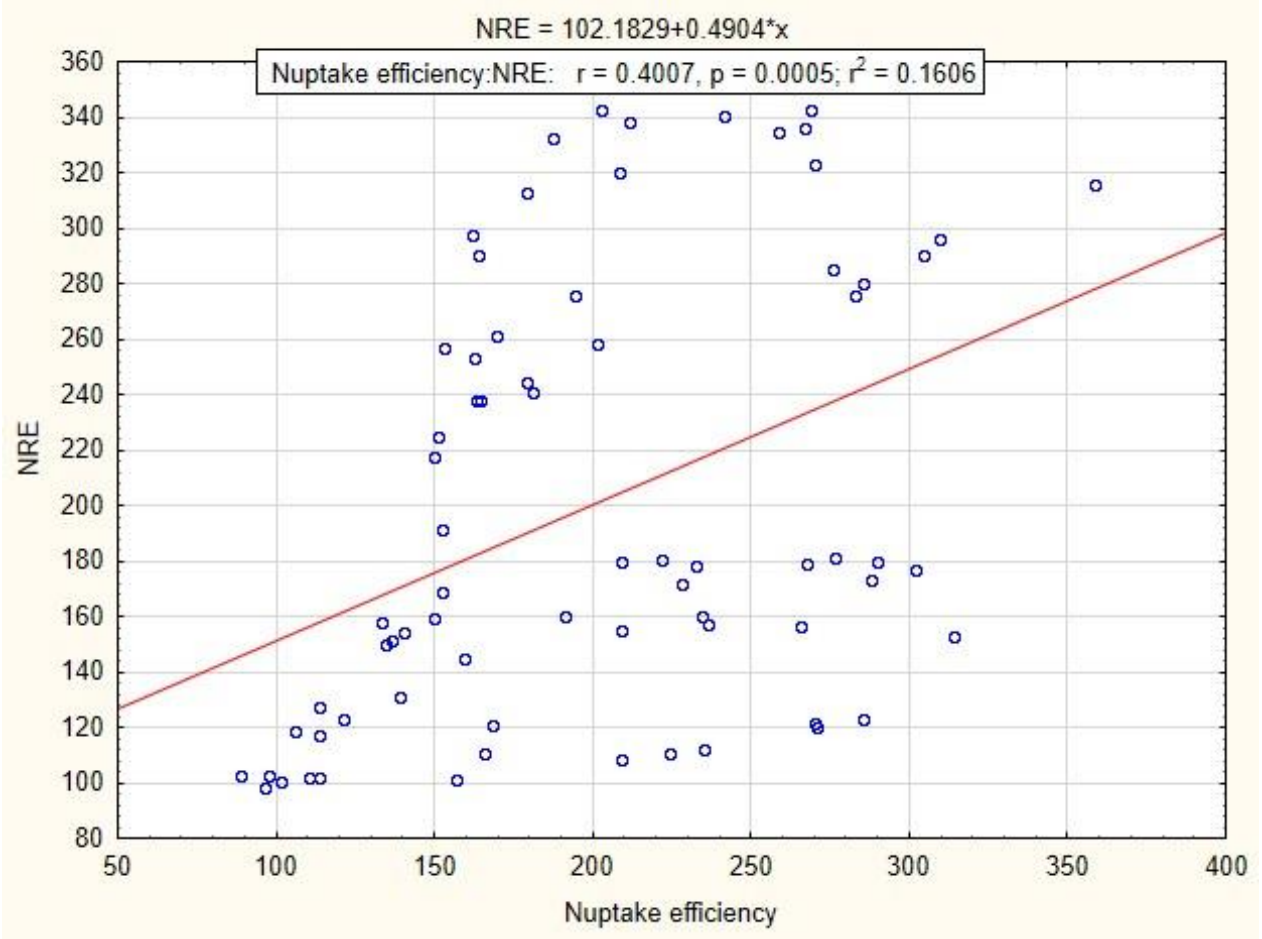

Figure 2. Correlations between $\mathrm{N}$ response efficiency (NRE) and $\mathrm{N}$ uptake efficiency in sown grassland.

\section{Conclusions}

Our findings show that NUE is significantly lower when N fertilizers are applied, revealing a different behavior of the three sward types analyzed: in Tp_mono and TpLm_mixt less $\mathrm{N}$ is being removed than has been applied, leaving some of the applied $\mathrm{N}$ in the soil; on the other hand Lm_mono used a high proportion of the $\mathrm{N}$ applied being at the limit to access $\mathrm{N}$ from the organic pool or residual $\mathrm{N}$ from fertilizer applications to a preceding crop. Our evidence indicates that NRE is highly influenced by the $\mathrm{N}$ uptake efficiency. We conclude that a combination of forage mixture combined with lower to medium $\mathrm{N}$ inputs could significantly contribute to increasing NUE while providing sustainable long-term grass yields across managed grasslands installed in similar conditions to those experimented in this study. Based on our findings, we recommend further studies in this direction (developing and improving the use of such indicators when evaluating sown/semi-natural grasslands $\mathrm{N}$ efficiency).

Author Contributions: This work is a combined effort of all the authors; conceptualization and designing the pot experiments, A.M., I.R. and R.V.; performing pot experiments and chemical analyses, A.M., F.P., C.M. (Cristina Moldovan) and V.I.; statistical analysis of data, and producing the presentation tables and figures, A.M. and C.M. (Cristian Mălinaș); writing the original draft with contributions from all of the authors, A.M. and C.M. (Cristian Mălinaș); reviewing and editing the whole manuscript, I.R., R.V. and A.M. All authors have read and agreed to the published version of the manuscript.

Funding: This research received no external funding.

Acknowledgments: The publication was supported by funds from the National Research Development Projects to finance excellence (PFE)-37/2018-2020 granted by the Romanian Ministry of Research and Innovation.

Conflicts of Interest: The authors declare no conflict of interest.

\section{References}

1. Tilman, D.; Balzer, C.; Hill, J.; Befort, B.L. Global food demand and the sustainable intensification of agriculture. Proc. Nat. Acad. Sci. USA 2011, 108, 20260-20264. [CrossRef]

2. Alexandratos, N.; Bruinsma, J. Food and Agriculture Organization of the United Nations, ESA Working Paper, 2nd ed.; World Agriculture towards 2030/2050: The 2012 Revision; FAO Agricultural Development Economics Division: Paris, France, 2012; pp. 3-12. 
3. Oenema, O. Nitrogen budgets and losses in livestock systems. Int. Congr. Ser. 2006, 1293, 262-271. [CrossRef]

4. Sutton, M.A.; Bleeker, A.; Howard, C.M.; Bekunda, M.; Grizzeetti, B.; de Vries, W.; van Grinsven, H.J.M.; Abrol, Y.P.; Adhya, T.K.; Billen, G.E.A. Our Nutrient World: The Challenge to Produce More Food and Energy with Less Pollution, 1st ed.; Centre for Ecology and Hydrology: Edinburgh, UK, 2013; pp. 17-25.

5. Erisman, J.W.; Leach, A.; Bleeker, A.; Arwell, B.; Cattaneo, L.; Galloway, J. An integrated approach to a nitrogen use efficiency (NUE) indicator for the food production-consumption chain. Sustainability 2018, 10, 925. [CrossRef]

6. Fixen, P.; Brentrup, F.; Bruulsema, T.; Garcia, F.; Norton, R.; Zingore, S. Nutrient/fertilizer use efficiency: Measurement, current situation and trends. In Managing Water and Fertilizer for Sustainable Agricultural Intensification, 1st ed.; Drechsel, P., Heffer, P., Magen, H., Mikkelsen, R., Wichelns, D., Eds.; International Fertilizer Industry Association (IFA): Paris, France; International Water Management Institute (IWMI): Paris, France; International Plant Nutrition Institute (IPNI): Paris, France; International Potash Institute (IPI): Paris, France, 2015; Volume 1, pp. 1-30.

7. Goulding, K.; Jarvis, S.; Whitmore, A. Optimizing nutrient management for farm systems. Philos. Trans. R. Soc. Lond. B Biol. Sci. 2008, 363, 667-680. [CrossRef] [PubMed]

8. Freibauer, A.; Kaltschmitt, M. Emission rates and emissions factors of greenhouse gas fluxes in arable and animal agriculture. In European Summary Report of the EU Concerted Action "Biogenic Emissions of Greenhouse Gases Caused by Arable and Animal Agriculture" (FAIR3-CT96-1877) Financed by EU DGVI Project Report Task 1; Institut furr Energiewirtschaft und Rationelle Energieanwendung (Universitat Stuttgart): Stuttgart, Germany, 2000; Available online: http://opus-ho.uni-stuttgart.de/hop/volltexte/2002/22/pdf/Freibauer_diss. pdf (accessed on 21 November 2019).

9. Sobkowicz, P.; Tendziagolska, E.; Agnieszka, L. Performance of multi-component mixtures of spring cereals. Agricultura Part 2. Competitive hierarchy and yield advantage of mixtures. Acta Sci. Pol. Ser. Agric. 2016, 15, 37-48.

10. Hiremath, A.J.; Ewel, J.J. Ecosystem nutrient use efficiency, productivity, and nutrient accrual in model tropical communities. Ecosystems 2001, 4, 669-682. [CrossRef]

11. Hack-ten Broeke, M.J.D.; Schut, A.G.T.; Bouma, J. Effects on nitrate leaching and yield potential of implementing newly developed sustainable land use systems for dairy farming on sandy soils in The Netherlands. Geoderma 1999, 91, 217-235. [CrossRef]

12. Pereira Serra, A.; Marchetti, M.E.; Dupas, E.; Candido Ensinas, S.; Reis Pinheiro Lourente, E.; Francisco da Silva, E.; Giolo de Almeida, R.; Eloize Carducci, C.; Tokura Alovisi, A.M. Best Management Practices (BMPs) for Nitrogen Fertilizer in Forage Grasses. In New Perspectives in Forage Crops, 1st ed.; Loiola Edvan, R., Bezerra, L., Eds.; IntechOpen: Rijeka, Croatia, 2018; pp. 131-146.

13. Rotar, I.; Păcurar, F.; Vidican, R.; Deak, D.; Mălinaş, A. The behavior of Medicago sativa and Bromus inermis mixture subjected to different conditions of fertilization. Bull. UASMV Ser. Agric. 2013, 70, 25-29.

14. Bridgham, S.D.; Pastor, J.; Mc Claugherty, C.A.; Richardson, C.J. Nutrient-use efficiency-A litter fall index, a model, and a test along a nutrient-availability gradient in North-Carolina peat lands. Am. Nat. 1995, 145, 1-21. [CrossRef]

15. Mastalerczuk, G.; Borawska-Jarmułowicz, B.; Kalaji, H.M.; Dąbrowski, P.; Paderewski, J. Gas-exchange parameters and morphological features of festulolium (Festulolium braunii K. Richert A. Camus) in response to nitrogen dosage. Photosynthetica 2017, 55, 20-30. [CrossRef]

16. Dalton, S.J.; Bettany, A.J.E. Co-transformed, diploid Lolium perenne (perennial ryegrass), Lolium multiflorum (Italian ryegrass) and Lolium temulentum (darnel) plants produced by microprojectile bombardment. Plant Cell Rep. 1999, 18, 721-726. [CrossRef]

17. Hejduk, S.; Kno, P. Effect of provenance and ploidity of red clover varieties on productivity, persistence and growth pattern in mixture with grasses. Plant Soil Environ. 2010, 56, 111-119. [CrossRef]

18. Kjeldahl, J. Neue Methods zur Bestimmung des Stickstoffs in Organischen Korpern. Fresenius' J. Anal. Chem. 1983, 22, 366-382. [CrossRef]

19. Raun, W.R.; Johnson, G.V. Improving nitrogen use efficiency for cereal production. Agron. J. 1999, 91, 357-363. [CrossRef]

20. Keeney, D.R. Nitrogen management for maximum efficiency and minimum pollution. Nitrogen Agric. Soils 1982, 22, 605-649. 
21. Pastor, J.; Bridgham, S.D. Nutrient efficiency along nutrient availability gradients. Oecologia 1999, 118, 50-58. [CrossRef]

22. Dobermann, A. Nitrogen use efficiency-State of the art. Agron. Hortic. Fac. Publ. 2005, 1-16.

23. Black, A.D.; Laidlaw, A.S.; Moot, D.J.; Kiely, P.O. Comparative growth and management of white and red clovers. Ir. J. Agric. Food Res. 2009, 48, 149-166.

24. Dhamala, N.R.; Rasmussen, J.; Carlsson, G.; Søegaard, K.; Eriksen, J. N transfer in three-species grass-clover mixtures with chicory, ribwort plantain or caraway. Plant Soil 2017, 413, 217-230. [CrossRef]

25. Wilsey, B.J.; Potvin, C. Biodiversity and ecosystem functioning: Importance of species evenness in an old field. Ecology 2000, 81, 887-892. [CrossRef]

26. Trenbath, B.R. Biomass productivity of mixtures. Adv. Agron. 1974, 26, 177-210.

27. Rotar, I. Studies Concerning Inter and Intraspecific Competition in Legume-Grass Forage Mixture. Ph.D. Thesis, University of Agricultural Sciences and Veterinary Medicine, Cluj-Napoca, Romania, 1994.

28. Daepp, M.; Suter, D.; Almeida, J.P.F.; Isopp, H.; Hartwig, U.A.; Frehner, M.; Blum, H.; Nösberger, J.; Lüscher, A. Yield response of Lolium perenne swards to free air $\mathrm{CO}_{2}$ enrichment increased over six years in a high $\mathrm{N}$ input system on fertile soil. Glob. Chang. Biol. 2000, 6, 805-816. [CrossRef]

29. Luo, J.; Klein, C.A.M.; Ledgard, S.F.; Saggar, S. Management options to reduce nitrous oxide emissions from intensively grazed pastures: A review. Agric. Ecosyst. Environ. 2010, 136, 282-291. [CrossRef]

30. Marschner, P.; Rengel, Z. Nutrient Cycling in Terrestrial Ecosystems; Springer: Berlin, Germany, 2007; p. 291.

31. Andrade, C.M.S.; Garcia, R.; Couto, L.; Pereira, O.G.; Souza, A.L. Desempenho de Seis Gramíneas Solteiras ou Consorciadas com o Stylosanthes guianensis cv. Mineirão e Eucalipto em Sistema Silvipastoril. Bras. Zootec. 2003, 32, 1845-1850. [CrossRef]

32. Olanite, J.A.; Tarawali, S.A.; Aken'ova, M.E. Biomass yield, quality and acceptability of selected grass-legume mixtures in the moist savannah of West Africa. Trop. Grassl. 2004, 38, 117-128.

33. Bruulsema, T.; Lemunyon, J.; Herz, B. Know your fertilizer rights. Crops Soils 2009, 42, 13-18.

34. Vidican, R.; Mihai, R.; Rotar, I.; Mărghitaş, M. Manualul Aplicarii Fertilizantilor, 1st ed.; Vidican, R., Ed.; Risoprint: Cluj, Romania, 2013; pp. 87-91.

35. Xu, G.; Fan, X.; Miller, A.J. Plant nitrogen assimilation and use efficiency. Annu. Rev. Plant Biol. 2012, 63, 153-182. [CrossRef]

36. Aerts, R. Nutrient use efficiency in evergreen and deciduous species from heathlands. Oecologia 1990, 84, 391-397. [CrossRef]

37. Vitousek, P. Nutrient cycling and nutrient use efficiency. Am. Nat. 1982, 119, 553-572. [CrossRef] 